Review

\title{
Anthocyanins and Their $\mathrm{C}_{6}-\mathrm{C}_{3}-\mathrm{C}_{6}$ Metabolites in Humans and Animals
}

\section{Wilhelmina Kalt}

Agriculture \& Agri-Food Canada (Retired). 212 Foley Road, RR\#3 Centreville, NS B0P 1J0, Canada; wilhelmina.kalt@icloud.com; Tel.: +1-902-300-9042

Academic Editor: Chiara Tonelli

Received: 9 October 2019; Accepted: 5 November 2019; Published: 7 November 2019

\begin{abstract}
Research on the bioavailability of anthocyanins has focused, historically, on the non-flavonoid $\left(C_{6}-C_{n}\right)$ products that arise from anthocyanins in vivo. However, this review focuses on the products of anthocyanins that still possess the flavonoid structure $\left(C_{6}-C_{3}-C_{6}\right)$. Described herein are aspects of the in vivo pool of $\mathrm{C}_{6}-\mathrm{C}_{3}-\mathrm{C}_{6}$ anthocyanin-derived intermediates. Properties related to molecular size, shape, and polarity conveyed by six major anthocyanidin structures are discussed. The presence of a glycoside or not, and a variety of possible phase 2 conjugates, gives rise to a chemically diverse pool of $\mathrm{C}_{6}-\mathrm{C}_{3}-\mathrm{C}_{6}$ intermediates. Chemical properties influence the in vivo stability of anthocyanin-derived products, as well as their suitability as a substrate for xenobiotic conjugation and transport, and their association with the biomatrix. The flavonoid structure is associated with bioactivity and the particular properties of these $C_{6}-C_{3}-C_{6}$ products of anthocyanins determines their deposition in the body, which may influence in vivo processes and ultimately health outcomes.
\end{abstract}

Keywords: bioavailability; enterohepatic; flavonoid; phase 2 metabolism

\section{Introduction}

Anthocyanidin pigments (Figure 1) are widely distributed in fruit, especially berries, and can be the most abundant flavonoid in deeply pigmented berry crops like blueberries. Like other flavonoids [1,2], anthocyanin pigments continue to be investigated for their human health benefits. The collective evidence suggests that anthocyanin intake is associated with anti-oxidation, anti-inflammation [3], and vaso-modulation benefits by acting as biochemical effectors via multiple mechanisms. Mechanisms of anthocyanin action are being elucidated using in vitro, in vivo, and clinical research approaches [4], which is supported by evidence from epidemiological (observational) analyses that specifically examine the contribution of anthocyanin intake to health outcomes and disease risk.

Greater anthocyanin intake is associated with a decreased risk of all-cause mortality [5] which can be mainly accounted for by a reduced cardiovascular mortality risk [6]. There are several meta-analyses that associate greater anthocyanin intake with reduced cardiovascular disease risk [6-10] and with improved markers of cardiovascular health [11-13]. Greater anthocyanin intake is also associated with a reduced risk of type 2 diabetes [14] and better weight maintenance [15]. Beyond cardiovascular and metabolic function, anthocyanin intake is also associated with a delayed decline in cognition during aging [16]. 


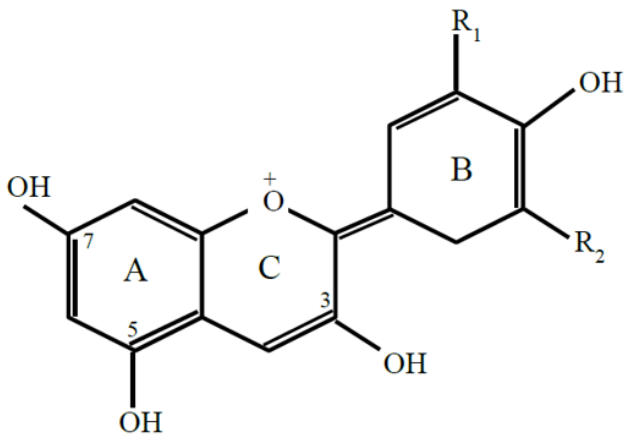

\begin{tabular}{|c|c|c|}
\hline Anthocyanidina & $\mathbf{R}_{1} \mathbb{a}$ & $\mathbf{R}_{2} \mathbf{a}$ \\
\hline Pelargonidin $a$ & $\mathrm{Ha}$ & $\mathrm{Ha}$ \\
\hline Cyanidin $x$ & $\mathrm{OH}$ & $\mathrm{Ha}$ \\
\hline Peonidin $\alpha$ & $\mathrm{OCH}_{3} \mathrm{a}$ & $\mathrm{Ha}$ \\
\hline Delphinidina & $\mathrm{OH}$ & $\mathrm{OHa}$ \\
\hline Petunidina & $\mathrm{OCH}_{3} \mathrm{a}$ & $\mathrm{OHa}$ \\
\hline Malvidina & $\mathrm{OCH}_{3} \mathrm{O}$ & $\mathrm{OCH}_{3} \mathrm{a}$ \\
\hline
\end{tabular}

Figure 1. Generic structure of the six major anthocyanidins found in plant foods. Sugar conjugates of anthocyanidins (i.e., anthocyanins) occur most commonly via an $O$-linkage at carbon-3 and/or carbon-5. Phase 2 methylation, glucuronidation, sulfation is possible at all hydroxyl groups, giving rise to multiple positional isomers.

In spite of a plethora of evidence for the beneficial effects of food forms of anthocyanin pigments (i.e., 'parent anthocyanins,' also called anthocyanidin glycosides) based on current bioavailability research, it is agreed that the concentration of parent anthocyanins in vivo would be too low to exert effects comparable to those observed in vitro [17]. It is also agreed that the absorption, digestion, metabolism and excretion (ADME) of anthocyanins is dynamic and complex. When anthocyanin ADME was investigated in a human study using ${ }^{13} \mathrm{C}$-labelled cyanidin-3-glucoside (C3g), rapid and complete anthocyanin breakdown was demonstrated when a significant proportion of the ${ }^{13} \mathrm{C}$-label was recovered as ${ }^{13} \mathrm{CO}_{2}$ in breath. However $56 \%$ of the ${ }^{13} \mathrm{C}$ label was still in the body $48 \mathrm{~h}$ after intake [18].

Factors that affect the dynamic retention of anthocyanins in the body are the focus of this review. The in vivo properties of anthocyanins, their interactions with abundant biomolecules, and the impact of human metabolism on them will be discussed. While the non-flavonoid products (i.e., $\mathrm{C}_{6}-\mathrm{C}_{\mathrm{n}}$ ) of anthocyanins have been very well-studied [19], this review focuses on the $C_{6}-C_{3}-C_{6}$-based products, which are worthy of attention, owing to their well-documented bioactivities [1,2].

\section{Anthocyanin Properties in Vivo}

\subsection{Water Activity and Anthocyanin Stability}

Whereas parent anthocyanins in aqueous conditions are unstable at neutral $\mathrm{pH}$ [20], they appear to be significantly stabilized in the biomolecular environment of the body [21-23], which relates at least in part to reduced hydration of flavylium ionic forms. For example, when pelargonidin glycoside's stability was tested at different hydration states (using glycerol, at $\mathrm{pH}$ 3.4) greater water activity was associated with greater degradation with a 20-fold range in room temperature half-lives (56-934 days) [24]. When the relative in vitro stabilities of the three glucosides of cyanidin, delphinidin, pelargonidin and their aglycones were compared at neutral $\mathrm{pH}$, B-ring structures with greater hydroxylation were associated with decreased stability [20].

The association of malvidin-3-glucoside (Mal3g) with anionic SDS micelles provided substantial stability and protected against $\mathrm{pH}$-related bleaching [25]. The effect on stability was attributed to modified hydration and deprotonation of the Mal3glu molecule [25]. In another study using circular 
dichroism, anthocyanin stability was improved by association with anionic SDS micelles, with evidence of intermolecular self-association [26]. Improved stability of anthocyanins in lipophilic and amphipathic micellar environments has relevance to their behavior in vivo in bile and tissues. Improved flavonoid stability by emulsification has been reported [27] and appears to be important for anthocyanins as well.

\subsection{Membrane Solubility of Anthocyanins}

Hydrophobicity. i.e., reduced polarity, is a key characteristic affecting the distribution of solutes between the lipophilic and hydrophilic environments of the cell. The behavior of solutes in the membrane can be modelled in vitro using micelles and liposome bilayers to provide a truer estimate of membrane solubility compared to the typical octanol-water partitioning, by taking into account the presence of membrane components. Using such methods, polarity was estimated using micellar electrokinetic chromatography (MEKC) and compared to octanol-water partitioning for a series of anthocyanin aglycones and glycosides in their uncharged forms at neutral pH (Figure 2) [28]. For both methods, cyanidin 3,5-diglucoside was the least membrane soluble, and substantially less so that cyanidin aglycone. Based on MEKC, pelargonidin 3,5-diglucoside showed the greatest capacity for partitioning into the membrane, similarly to delphinidin aglycone. Whereas octanol-water partitioning showed a strong effect of glycosylation, MEKC illustrated the more complex membrane partitioning behaviour of anthocyanidins, which is influenced by both their glycosylation and B-ring hydroxylation (Figure 2) [28].

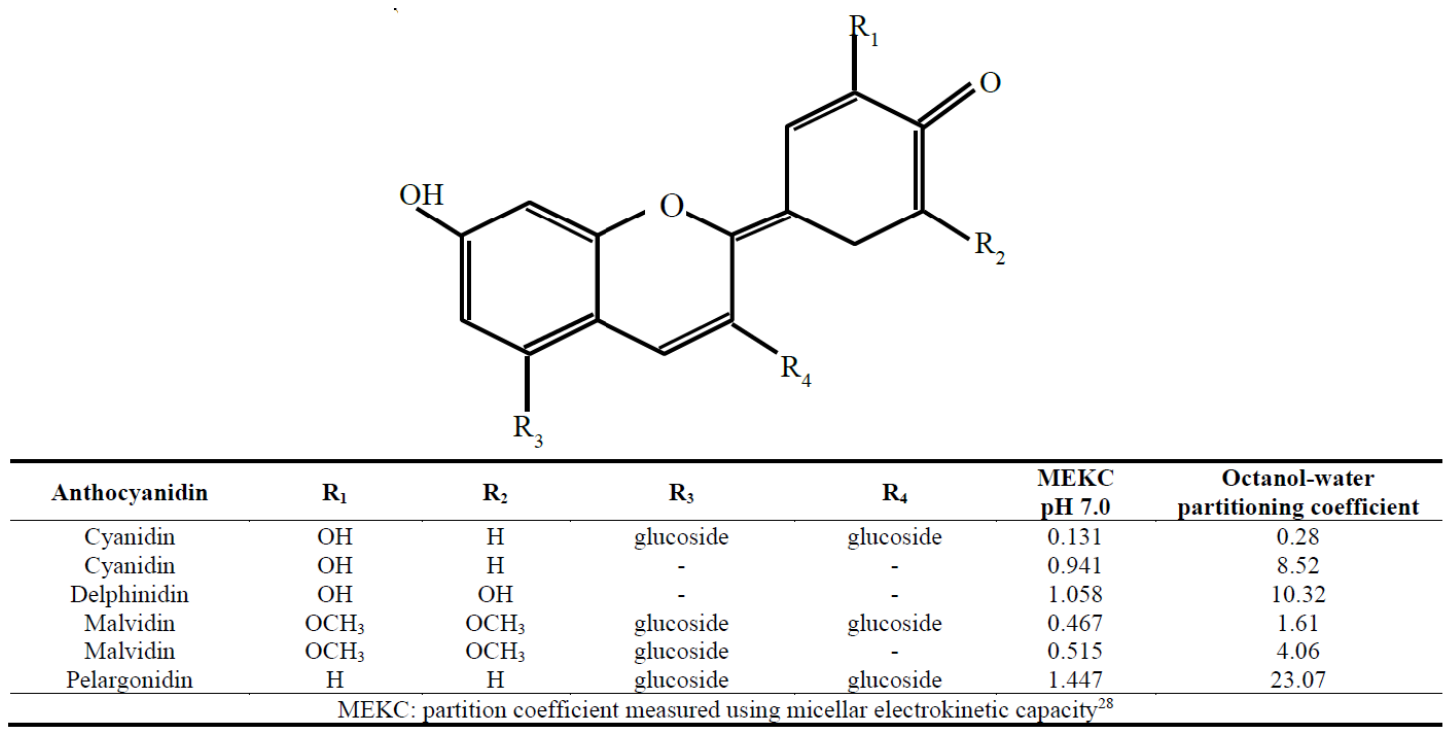

Figure 2. Partition coefficients of selected anthocyanidins and anthocyanins based on micellar electrokinetic methods and octanol-water partitioning [28].

Typically, deglycosylation of anthocyanins, which is rapid and extensive in vivo, produces an anthocyanidin (i.e., aglycone) which has significantly reduced molecular polarity and greater membrane solubility [29]. The reduced polarity of the small and less-polar molecule enables the paracellular transfer of solutes into cells, independent of membrane transporters, and therefore, provides a means to by-pass carrier-mediated transport.

\subsection{Anthocyanin Association with Human Serum Albumin}

The intense staining properties of anthocyanins are evidence of their propensity to adsorb to biomolecules, such as protein and polysaccharide [30]. Flavonoid adsorption to protein [31] is particularly relevant in relation to human serum albumin, which can both circulate and act as a depot for compounds. Anthocyanins interact with human serum albumin via hydrophobic and electrostatic 
interactions, which are favored by hydroxyl groups but not by methyl groups [32]. At $\mathrm{pH}$ 7.4, electrostatic interactions predominate, but at the acidic $\mathrm{pH}$ of the stomach, associations are due to hydrophobic effects [32]. Binding to human serum albumin was more favorable for anthocyanins than for anthocyanidins [32]. It has been suggested that the recovery of anthocyanins from plasma may be negatively affected by their binding to plasma proteins [33]. Anthocyanins are also reported to be associated with unidentified proteins in the stomach [22].

\subsection{Anthocyanins in the Intestinal Tract}

A mucus layer lines the gastrointestinal tract (GIT) which permits nutrient uptake and excludes bacteria and other toxic compounds. Evidence of a close physical association with mucin was suggested when almost $80 \%$ of anthocyanins administered could still be recovered from the small intestine of mice $2 \mathrm{~h}$ after gastric administration [22]. It is possible that a greater proportion of parent anthocyanin could survive first-pass metabolism when delivered in a large dose, if the capacity for first-pass metabolism becomes saturated.

All that notwithstanding, there is evidence that anthocyanin uptake into enterocytes could be impeded by an anthocyanin association with mucin. Evidence for mucin's effects include a study showing that when a large blackberry dose preceded a small dose, C3g absorption from the small dose was reduced compared to when the first dose was small [34]. Further evidence is that both total and parent anthocyanin content declined in human urine during $28 \mathrm{~d}$ of daily blueberry juice intake $(n=18)$ and even a $7 \mathrm{~d}$ wash-out did not change this declining trend [35]. Additionally, anthocyanin tissue bioavailability was markedly reduced in studies where a high, compared to a low, anthocyanin dose was used [36]. No anthocyanin was detected in brain, where it was expected, in a study that used high anthocyanin doses in food (500-600 mg/day) [37]. In a long-term human study, the urinary content of parent anthocyanins was greater when a daily blueberry juice dose was taken in $250 \mathrm{~mL}$ in the morning, rather than in three $83 \mathrm{~mL}$ doses over a $12 \mathrm{~h}$ period. This suggested that greater intestinal coverage improved the capacity for anthocyanin absorption [35].

In support of this notion, it has also been suggested that cationic anthocyanins bind to intestinal mucus [27]. But when anthocyanins are incorporated in mixed micelles with bile salts thereby changing their surface charge, anthocyanins can pass more readily through mucin due to modified solubility behavior $[27,38]$. It has also been hypothesized that anthocyanin stability is improved by binding to intestinal mucus, secretions, and food residues [21,22].

Closely associated with the mucin barrier is the gut-associated lymphoid tissue which conducts immune function for the host, in relation to gut and external microbiota [39]. Achieving translocation through the mucin layer and the enterocyte, makes anthocyanins available for association with capillaries and/or lymph vessels. Whereas hydrophilic solutes are mainly transported via plasma, hydrophobic solutes, including lipids, are transported in the lymph. It is interesting to consider how anthocyanin's association with lymph could modulate immune function between the host and its gut microbiome. Phase 2 conjugates of quercetin were found in lymph, although quercetin aglycone was not [40].

With respect to food interactions in the GIT, when strawberries were eaten with cream, the $T_{\max }$ of pelargonidin products was delayed compared to without cream, but recovery was not affected [41]. It is possible that the presence of cream and fat delayed gastric emptying and the absorption of anthocyanins from the small and large intestine. A similar result was obtained with both quercetin glycoside and aglycone, whose absorptions were increased when delivered with high fat [42].

\section{Uptake of Parent Anthocyanins on the Bilitranslocase}

Intact parent anthocyanins can enter circulation directly and rapidly via the gastric bilitranslocase [43]. The bilitranslocase is an organic ionic membrane carrier whose best-characterized substrates are bilirubin, nicotinic acid, and sulfobromophtalein [43]. Whereas other flavonoids are not effective ligands for the bilitranslocase [44], anthocyanins meet the structural specifications, thereby 
providing a means for them to be absorbed directly without deglycosylation [43,45]. The structural interaction of anthocyanin on the bilitranslocase occurs preferentially via the glycoside moiety, thereby making anthocyanins better substrates than anthocyanidins [43].

Anthocyanins are transported across the bilitranslocase and into circulation in significant amounts. When glycosides of cyanidin, delphinidin, and malvidin contained in bilberries were administered to the stomach, absorption ranged between about $20 \%$ and $40 \%$, with the greatest uptake being for delphinidins [34], noting that "absorption" could be due to uptake or loss. Anthocyanin uptake by the gastric bilitranslocase has been reported to correlate well with total intestinal uptake, suggesting that it is an important route for anthocyanin uptake [43]. Isoforms of the bilitranslocase are located at multiple sites, including the epithelia of the gastric cavity, jejunum, liver, kidney, and the vascular endothelium $[43,44]$.

\section{Parent Anthocyanin Conversion into $\mathrm{C}_{6}-\mathrm{C}_{3}-\mathrm{C}_{6}$ Products in Vivo}

Anthocyanins, like other flavonoids, are subject to extensive first-pass metabolism involving intestinal and hepatic metabolic machinery, including conjugation enzymes and membrane transporters $[27,44,46]$. In humans, the profile of $C_{6}-C_{3}-C_{6}$ conjugates of anthocyanins reflects the collective impact of substrate and location specificity in xenobiotic machinery, its phenotypic variation, and to a limited extent, microbial activity, plus the influences of the in vivo matrix.

\subsection{Deglycosylation}

Anthocyanins occur in plants entirely as glycosidic forms, where they are localized in the cell's large acidic vacuole. After ingestion by animals, anthocyanins are deglycosylated thereby releasing glycoside group(s) and anthocyanidins; i.e., aglycones. For many flavonoid glycosides, glycoside hydrolysis is necessary for aglycone absorption to occur [45].

Anthocyanidin glycoside hydrolysis can occur in the mouth via $\beta$-glycosidase activity, which is mainly of bacterial origin [47]. Anthocyanins in the small intestine can enter the enterocyte without deglycosylation via the sodium-coupled glucose transporter. And once inside the enterocyte, they can be deglycosylated via the cytosolic $\beta$-glycosidase. Otherwise anthocyanins can enter the enterocyte with glycoside hydrolysis on the lactase phlorizin hydrolase. Both the sodium-coupled glucose transporter and the lactase phlorizin hydrolase are localized on the apical side of the enterocyte [48].

Extensive deglycosylation of ${ }^{13} \mathrm{C}$-labelled C3g in humans was apparent, because none of the 24 ${ }^{13} \mathrm{C}$-labelled metabolites detected, were glycosylated [18]. However, it has been suggested that human $\beta$-glucosidase may be insufficient to totally deglycosylate anthocyanins due to very high phenotypic variation [49]. The intestinal $\beta$-glucosidase probably makes a greater contribution to total anthocyanin deglycosylation than does the liver's $\beta$-glycosidase activity [48].

Food anthocyanins with less common glycosides, including acylated forms, can be resistant to human $\beta$-glycosidase activities and are more readily hydrolyzed by various bacterial $\beta$-glycosidases in the colon. Thus, the pharmacokinetics of mono-glycosidic anthocyanin forms can be distinct from anthocyanins with larger and more complex O-glycoside substitutions [50-52].

\subsection{First-Pass Metabolism}

Despite rapid and extensive deglycosylation, very few studies detect simple anthocyanidins (i.e., aglycone forms) in plasma and urine [53-56] which is consistent with the diminished aqueous solubility and stability of anthocyanidins. Anthocyanidins are substrates for phase 2 conjugation, involving glucuronidation via uridine $5^{\prime}$-diphosphate-glucuronosyltransferases, methylation via catechol-O-methyl transferase, and sulfation via sulfotransferases. Indeed anthocyanidins are strongly preferred over anthocyanins, as substrates for conjugation [45]. Typically, the most abundant phase 2 conjugates are methylated and glucuronidated anthocyanidins and anthocyanins [18,55,57-61]. Flavonoid glucuronidation occurs via uridine 5 '-diphosphate-glucuronosyltransferase, which occurs in various isoforms at many different sites in the body [62,63]. Although phase 1 hydroxylation via 
cytochrome oxidases can occur, it is probably not a major pathway for flavonoids [45,62]. Notably, hydroxylation creates new reactive sites for phase 2 conjugation. Specificity in phase 2 conjugation enzymes and membrane carriers and efflux transporters, particularly those in the ATP-binding cassette transporter group, determine the site-specific in vivo pool of $C_{6}-C_{3}-C_{6}$ metabolites derived from anthocyanins.

\section{Enterohepatic Circulation}

During enterohepatic circulation (EHC), solutes are selectively absorbed from the upper GIT and moved via the portal vein to the liver, where xenobiotic conjugation can occur. Solutes and their xenobiotic conjugates are incorporated into bile. Bile is released sporadically into the upper small intestine (ileum) to aid in food particle and fat absorption. After their release into bile, solutes including phase 2 conjugates, migrate down the GIT, where they can be deconjugated by human or bacterial enzymes. To remain in EHC, products are absorbed from the small and large intestine and returned to the liver via portal flow. To exit EHC, solutes and their metabolites are excreted in urine and feces or are deposited into tissue reservoirs [64]. EHC is manifested by a delayed clearance of a solute [64]. The most definitive and informative means to investigate EHC is with surgical cannulation models, which are possible in rodents but not in humans.

\subsection{Factors Affecting EHC Uptake}

Chemical factors that influence the capacity for a compound to be taken up into EHC include molecular weight (MW), structure, and polarity, with MW being the most consistent factor [64]. In humans, GIT solutes of about MW 500-600 preferentially enter EHC [64]. This MW range includes many flavonoid (i.e., $\mathrm{C}_{6}-\mathrm{C}_{3}-\mathrm{C}_{6}$ ) glycosides and glucuronide conjugates. Lower $\mathrm{MW}$ phenolic acids (i.e., $\mathrm{C}_{6}-\mathrm{C}_{\mathrm{n}}$ ) and esters, including chlorogenic, ferulic, and caffeic acids, appear to be much less readily taken up into EHC based on studies using surgically cannulated rats [65]. Although many factors influence biliary uptake [64] differences in EHC uptake significantly distinguish the pharmacokinetics of the $\mathrm{C}_{6}-\mathrm{C}_{3}-\mathrm{C}_{6}$ and $\mathrm{C}_{6}-\mathrm{C}_{n}$ products arising from anthocyanins.

\subsection{Flavonoids in EHC}

Large, structure-specific effects were found in the secretions of various flavonoids into bile, using surgical cannulation with perfusion in rats [66]. Among six classes of flavonoids, secretion into bile ranged from $1 \%$ for the flavan-3-ol catechin, to $32 \%$ for the isoflavone genistein. Plasma content for genistein was $1.34 \mu \mathrm{M}$ which was five times higher than for catechin $(0.24 \mu \mathrm{M})$ [66]. The high bioavailability of genistein was due to high uptake into bile and EHC [67]. Aspects of enteric and enterohepatic pathways for various flavonoids have been reported $[45,63,68]$ and reviewed [69].

\subsection{Anthocyanins and EHC}

Varied evidence suggests that anthocyanins can be taken up into EHC. Like other flavonoid classes, anthocyanins, anthocyanidins and their phase 2 conjugates are in the approximate MW range of 500-600; that is, they are amenable to uptake into EHC by humans [64]. Anthocyanin products with the $\mathrm{C}_{6}-\mathrm{C}_{3}-\mathrm{C}_{6}$ structure are strongly associated with bile phospholipids in urine. Indeed anthocyanin and anthocyanidin metabolites co-purified with highly amphipathic bile phospholipids in urine, although $>90 \%$ of the dry matter was removed during solid phase extraction [61].

During EHC, the sporadic release of bile gives rise to delayed clearance and even multiple peaks in excretion, which has been reported for delphinidin and petunidin glucoside and their glucuronides, after grape juice intake [70]. By using a Ussing chamber and other sections of the mouse GIT, anthocyanin uptake was shown to be highest in the jejunum [54] which is a major site of EHC uptake. Methylated and glucuronidated C3g conjugates appeared in bile soon after C3g was introduced into the small intestine [23]. 
Intestinal absorption of pelargonidin rutinoside was increased from $0.5 \%$ to $18 \%$ when biliary flow was surgically interrupted, suggesting a significant capacity for uptake by pelargonidin rutinoside into EHC [71]. Six minutes after grape anthocyanins were administered to the gastric cavity, portal and systemic blood flows were 0.65 and $0.234 \mu \mathrm{M}$ respectively [72], showing that a significant fraction of portal flow was available for biliary circulation.

\section{Structural Specificity in Anthocyanin's Behavior in Vivo}

An often-asked question regarding anthocyanin's health benefits is whether the six major anthocyanidins differ in their ADME, and how this may relate to their in vivo bioactivity. Investigating the xenobiotic methylation and hydroxylation of anthocyanins is challenging based on MS/MS because anthocyanidins (i.e., cyanidin, delphinidin, malvidin, pelargonidin, peonidin, and petunidin) are themselves differentiated from each other by their arrangement of methyl and hydroxyl groups on the B-ring. For example, although peonidin occurs in plants, peonidin (i.e., methyl cyanidin) also arises in animals from phase 2 methylation of cyanidin. Similarly, the removal of functional groups will interconvert anthocyanidins; for example, the loss of a hydroxyl group from the B-ring of cyanidin gives rise to pelargonidin $[53,56]$. Methylation and glucuronidation occurs at hydroxyl groups, which are abundant in anthocyanins and other flavonoids (Figure 1). Therefore, positional isomers of anthocyanin and anthocyanidin conjugates are predicted and indeed detected $[21,41,53,55,56,59,73]$. Greater complexity in the pool of $\mathrm{C}_{6}-\mathrm{C}_{3}-\mathrm{C}_{6}$ metabolites can be expected because of EHC and prolonged exposure to enteric and hepatic phase 2 metabolism.

\subsection{Cyanidin Metabolism and Products}

Cyanidin is the most widely distributed of the six major plant anthocyanidins and also the best-studied with respect to food and health. Isotopically-labeled $\mathrm{C} 3 \mathrm{~g}$ was used to definitively examine the absorption and metabolism of ${ }^{13} \mathrm{C} \mathrm{C} 3 \mathrm{~g}$ in humans [18] and ${ }^{14} \mathrm{C} \mathrm{C} 3 \mathrm{~g}$ in mice [74]. In the human study [18] at $48 \mathrm{~h}$ after intake, $44 \%$ of the ${ }^{13} \mathrm{C}$ label had been excreted in urine (5.4\%), breath (6.9\%), and feces (32.1\%). The exhalation of ${ }^{13} \mathrm{CO}_{2}$ derived from anthocyanin catabolism, which demonstrated complete catabolism of $\mathrm{C} 3 \mathrm{~g}$, continued throughout the $48 \mathrm{~h}$ study [18]. Also striking was that more than $50 \%$ of the ${ }^{13} \mathrm{C}$ label was still in the body at $48 \mathrm{~h}$. The authors attributed slow clearance of ${ }^{13} \mathrm{C}$ to EHC, and/or prolonged colonic metabolism and catabolite absorption [18]. Other factors may be interaction with intestinal mucin, protein, food materials, or other matrix components [22].

In the mouse study that administered orally, a single dose of ${ }^{14} \mathrm{C} \mathrm{C} 3 \mathrm{~g}$, almost $90 \%$ of the ${ }^{14} \mathrm{C}$ label was in the adipose tissue and gastrointestinal tissue and contents, $3 \mathrm{~h}$ later. After $24 \mathrm{~h}$, about $50 \%$ of the ${ }^{14} \mathrm{C}$ was accounted for in feces, and 3.3\% in urine [74]. These isotope studies suggest that anthocyanin clearance may be slower in humans than in mice. Whereas the ratio of ${ }^{13} \mathrm{C}$ labelled $\mathrm{C}_{6}-\mathrm{C}_{\mathrm{n}}$ products and ${ }^{13} \mathrm{C}-\mathrm{C} 3 \mathrm{~g}$ was 42 in humans [18], this ratio was only 6 in mice for ${ }^{14} \mathrm{C}$ [74], suggesting a longer period for catabolism in the human GIT. Very large variation in ${ }^{13} \mathrm{C}$ pharmacokinetics was noted in the human study. The recovery percentage of ${ }^{13} \mathrm{C}$ among eight human subjects ranged from $15 \%$ to $99 \%$. Additionally, the maximum plasma concentration of ${ }^{13} \mathrm{C}$ ranged from 10 to $2000 \mathrm{nM}$ and $\mathrm{T}_{\max }$ ranged from 2 to $20 \mathrm{~h}$ [18].

The ADME of C3g has been examined using various intervention models and with progressively more advanced approaches to chemical and data analysis. Notwithstanding the diversity of approaches, studies concur that methylation and glucuronidation are major routes of $\mathrm{C} 3 \mathrm{~g}$ conjugation in vivo. Among three human studies, which tracked $\mathrm{C}_{6}-\mathrm{C}_{3}-\mathrm{C}_{6}$ metabolites in urine after a single dose of either pure C3g [18], or after C3g-rich blackberries [75], or after boysenberries which contain cyanidin mono-glucosides, di-glucosides, and two cyanidin rutinosides [53], the metabolites detected in all these studies included methyl and glucuronide conjugates of $\mathrm{C} 3 \mathrm{~g}$, methyl $\mathrm{C} 3 \mathrm{~g}$ (i.e., peonidin-3-glucoside, Peo3g), cyanidin, and peonidin $[18,53,75]$. In one case, excretion of $C_{6}-C_{3}-C_{6}$ products in urine was still underway after $24 \mathrm{~h}$ at levels many times greater than C3g [75].

Also detected in these studies were the unconjugated simple aglycones, cyanidin and peonidin $[18,53,75]$. Aglycone flavonoids are much better substrates than glycosides as substrates 
for phase 2 conjugating enzyme [45]; however, anthocyanidins (i.e., aglycones) are very unstable in aqueous conditions. The conditions in vivo that stabilize anthocyanidins are unknown. And it is likely that the fate of anthocyanidins would depend on whether phase 2 conjugation could occur, instead of irreversible C-ring fission with loss of the flavonoid structure.

A substantial amount of C3g metabolism appears to occur in the liver. When C3g was administered to the stomachs of rats, both C3g and Peo3g were found in bile, whereas only C3g was found in plasma (35). When C3g was administered orally to rats, methylated and glucuronidated cyanidin was detected in plasma [73], but when C3g was given by IV, two methylated isomers of C3g, but no glucuronidated forms, were detected [73].

When C3g was administered by IV, methylated C3g in plasma rose and fell quickly which reflected either absorption (into tissues) and/or decomposition from circulation [76]. Other pathways of xenobiotic metabolism were apparent because small amounts of delphinidin, petunidin, malvidin, and pelargonidin glycoside were also detected in plasma, reflecting C3g methylation, hydroxylation, and dehydroxylation reactions [76]. With respect to the area under the curve for plasma, the ranking was C3g > Mal3g > Peo3g > pelargonidin-3-glucoside [76]. Similar results were obtained in another study where, after $\mathrm{C} 3 \mathrm{~g}$ injection, trace amounts of the 3-glycosides of malvidin > delphinidin > petunidin, occurred transiently in the plasma and kidneys which reflected xenobiotic methylation and hydroxylation capacity [77].

\subsection{Malvidin Metabolism and Products}

Malvidin is the largest, most methylated, and most hydrophobic of the six common food anthocyanidins, and for this reason has a somewhat distinctive ADME [78]. Among 13 studies that qualified for inclusion in a systematic review on anthocyanins in animal tissues, the highest concentration reported was that of Mal3g which was found in brain tissue $(4.43 \mathrm{pmol} / \mathrm{g})$ of young swine that were fed bilberry extract at $82.5 \mathrm{mg} / \mathrm{kg} /$ day for 3 weeks [79]. In another study with swine, three malvidin glycosides (galactoside, glucoside, and arabinoside) were the most abundant among 12 anthocyanins detected in two brain regions, eyes, and livers of blueberry-fed pigs [80]. Mal3g content contributed at least 50\% to the total anthocyanins detected in these tissues [80]. Mal3g and malvidin-3-galactoside were the most abundant of ten anthocyanins detected in brain tissue [81]. Mal3g and malvidin-3-galactoside were predominant in the plasma and tissues of mice after both a single dose and long-term feeding of bilberry anthocyanins although malvidin glycosides were only about $15 \%$ of the total bilberry anthocyanins [82]. This result illustrates the capacity for phase 2 methylation of anthocyanins in vivo in mice.

In a long-term study with humans $(n=17)$ consuming blueberry juice, malvidin glycosides (including the 3-glucoside, galactoside, and arabinoside) were three of only four anthocyanins that were statistically grouped among the 55 most abundant urinary anthocyanin metabolites [56]. The other abundant $\mathrm{C}_{6}-\mathrm{C}_{3}-\mathrm{C}_{6}$ metabolites were mostly deglycosylated forms, including methyl and glucuronide conjugates of all six common anthocyanidins [56]. Together, these pig and rodent studies examining tissues and fluids suggest that malvidin glycosides may be resistant to metabolism due to their bulkiness and degree of methylation [83]. The enzymatic capacity for methylation of petunidin glucoside to form Mal3g has been documented [84]

\subsection{Pelargonidin Metabolism and Products}

During anthocyanin breakdown in vivo, human and microbial-catalyzed demethylation and dehydroxylation of more highly substituted anthocyanins and anthocyanidins gives rise to pelargonidin. The removal of functional groups to yield pelargonidin glycoside and pelargonidin helps to explain the high apparent recovery of pelargonidin-based metabolites [21,85-87]. Pelargonidin glucuronide was detected in urine and attributed to cyanidin dehydroxylation in a boysenberry study where four different cyanidin glycosides were fed to humans [53]. Pelargonidin glucuronides could also arise from the catabolism of more highly substituted anthocyanidin glucuronides. Pelargonidin-3-glucoside was detected when Cy3g was administered by IV [76]. 
Blueberries contain only five of the six types of anthocyanidins; they do not contain pelargonidin glycosides [88]. During long term blueberry juice intake, pelargonidin-based metabolites, although absent from blueberry juice, were abundant in urine [56] when detected using HPLC-MS/MS. It is interesting to consider whether pelargonidin glycosides could serve as a flavonoid-based biomarker of anthocyanin intake. Indeed, pelargonidin was determined to be the most membrane soluble among a selection of anthocyanidin glycoside and aglycones [28].

\section{Anthocyanin Retention in Membranes and Tissue}

\subsection{Anthocyanins in Tissues}

In a recent review, two hundred seventy nine publications on the topic of anthocyanin tissue bioavailability were identified, of which thirteen met the review's inclusion criteria [78]. Of the thirteen, five studies examined anthocyanin tissue bioavailability after a single dose [55,77,89-91]. Four studies examined a single IV administration of anthocyanins $[55,76,77,90]$. Six studies examined anthocyanin in tissues after long-term feeding in rodents and pigs [36,79,81,82,89,92]. Parent anthocyanins and their phase 2 metabolites have been detected in many tissues where they have been sought, with exceptions [37,82,91]. Among the thirteen studies reviewed in detail, anthocyanin content was greatest in mice kidneys $\left(2.17 \times 10^{5} \mathrm{pmol} / \mathrm{g}\right)$, liver $\left(1.73 \times 10^{5} \mathrm{pmol} / \mathrm{g}\right)$, heart $\left(3.6 \times 10^{3} \mathrm{pmol} / \mathrm{g}\right)$, and lungs $\left(1.16 \times 10^{5} \mathrm{pmol} / \mathrm{g}\right)$, and in pig brain $\left(6.08 \times 10^{3} \mathrm{pmol} / \mathrm{g}\right)[78]$.

Anthocyanin appears to have a high affinity for tissues. In a blueberry study, where control pigs consumed a basal ( $0 \%$ blueberry) diet that contained anthocyanins from grain equivalent to $0.0002 \%$ of the blueberry powder, measurable amounts of parent anthocyanins were detected in pig tissues [80]. Although it is not possible to analyze human tissue for anthocyanin, there is no obvious reason why anthocyanins would not also be in human tissue.

Studies that were not included in the review by Sandoval-Ramirez also report anthocyanin in tissues of rodents following a single dose of berries [93,94] and in pigs during long-term anthocyanin feeding [80]. In one rat-feeding study, parent anthocyanins and some phase 2 methylated and glucuronidated forms were detected in GIT, liver, kidney, and brain tissues [93]. Among GIT tissues, anthocyanins were 10-times more abundant in the jejunum, which is a major site of EHC uptake, compared to other gastric tissues [93].

\subsection{Anthocyanin Beyond the Blood Brain Barrier}

Among the thirteen studies reviewed in detail [78] seven studies attempted to detect anthocyanin in brain tissues after either a single anthocyanin dose [76,82,90] or after long term anthocyanin feeding $[37,79,81]$. In two single-dose studies, anthocyanin was detected in other tissues but not the brain [82,95]. In a long term feeding study [37], anthocyanins were not detected in plasma or tissues, which may be attributed to the high anthocyanin dose fed ( $8 \%$ blueberries), as discussed earlier.

Anthocyanins were detected in brain tissue within $10 \mathrm{~min}$ after grape anthocyanins were incubated in the gastric cavity. For some of the grape anthocyanins, levels in brain tissue were comparable to levels found in plasma [94]. When anaesthetized rats received C3g by IV injection, C3g was detected in the brain tissue within $15 \mathrm{sec}$ and found at a concentration comparable to that in serum [76]. Indeed, anthocyanin content in the brain was found to correlate with plasma levels over a wide range [76]. When anthocyanin was administered by IV, fewer anthocyanin metabolites were found in brain tissue compared to plasma, suggesting carrier-mediated transport across the blood brain barrier [76].

In a study where a bilberry-enriched diet was fed to young swine for 3 weeks, dose-dependent levels of malvidin-, delphinidin- and cyanidin-galactoside and petunidin, Peo3g, and C3g were reported in various brain regions [79]. In another study where pigs were fed $2 \%$ for blueberries ad libitum for 8 weeks, phase 2 metabolites of anthocyanins were detected in the brain, including glucuronides of cyanidin, malvidin, peonidin, delphinidin, and petunidin. These were identified in the cortex, cerebellum, and the midbrain, plus in the diencephalon in combination [81]. 
Anthocyanin was detected in the whole eye of pigs that were fed $0 \%, 1 \%, 2 \%$, and $4 \%$ blueberry powder, in a manner that appeared to be dose dependent [96]. Following intraperitoneal administration of anthocyanins to rats, they were detected in the whole eye and in some ocular tissues at a level higher than in plasma [97]. When anthocyanins were administered intraperitoneally to rabbits, they were differentially distributed among several ocular tissues, and were particularly rich in the connective tissue of the sclera and cornea [97].

\section{How Anthocyanin-Derived $C_{6}-C_{3}-C_{6}$ Products May Work in Vivo}

Parent anthocyanins can survive transit through the GIT and be excreted intact in feces, which is evident by the purple anthocyanin pigmentation seen in the feces of birds and other animals that consume large amounts of berries.

\subsection{The Pool of Anthocyanin Products in the Body}

Products arising from anthocyanin metabolism and catabolism either possess or not, the diphenyl propanoid backbone characteristic of flavonoids. Many papers suggest that non-flavonoid breakdown products (i.e., catabolites) of anthocyanins, i.e., $\mathrm{C}_{6}-\mathrm{C}_{n}$, phenolic acids, and aldehydes, are responsible for health benefits [98-101]. To determine the relative contributions of $C_{6}-C_{3}-C_{6}$ and $C_{6}-C_{n}$ metabolites to anthocyanin health benefits, it is important to note that some $C_{6}-C_{n}$ phenolic products are present in other fruits and vegetables (e.g., syringic, vanillic, and gallic acids) [102] that are devoid of anthocyanins. Indeed, catabolites of anthocyanins contribute to an already very large pool of low MW phenolic moieties in the GIT. Further evidence for a special role for anthocyanins in health is that abundant phenolic moieties do not explain the in vitro effects of parent anthocyanins. Additionally, $C_{6}-C_{n}$ phenolics cannot explain the growing epidemiological evidence that specifically associates moderate anthocyanin intake with disease risk reduction and improved health outcomes [6-8,14-16].

\subsection{Slow Clearance of $C_{6}-C_{3}-C_{6}$ Metabolites from Human Urine}

In a long-term blueberry juice intake study, multiple positional isomers of methylated and glucuronidated anthocyanin and anthocyanidins were detected in human urine, for a total of 45 major $\mathrm{C}_{6}-\mathrm{C}_{3}-\mathrm{C}_{6}$ conjugates. These products were detected using LC-MS/MS analysis of 18 parent and 43 predicted metabolites for all six anthocyanidins $[35,56]$. The feeding trial also demonstrated the protracted release of $\mathrm{C}_{6}-\mathrm{C}_{3}-\mathrm{C}_{6}$ metabolites, even after no anthocyanin intake for 5 days [61]. The continued release of $\mathrm{C}_{6}-\mathrm{C}_{3}-\mathrm{C}_{6}$ metabolites was attributed to their release from EHC and tissue reservoirs. These findings are supported by a long-term, placebo-controlled blueberry study in humans showing even more protracted release of $\mathrm{C}_{6}-\mathrm{C}_{3}-\mathrm{C}_{6}$ metabolites in the urine of the placebo group, while cognitive improvements were associated with parent anthocyanins in the urine of the blueberry group (Krikorian et al. in press).

\subsection{How $C_{6}-C_{3}-C_{6}$ Products from Anthocyanins May Work in Vivo}

It is plausible that anthocyanin-derived products could be associated with the biomatrix and escape detection using conventional analytical approaches. This aspect would support a role of anthocyanin products in antioxidant protection. Abundant anthocyanins in the GIT, both at the membrane surface and in intestinal contents, can act as antioxidants against reactive oxygen species in the GIT, especially in the colon where the levels of Vitamin C and carotenoids are limited, but flavonoids are present [103]. Antioxidant protection may also be provided to tissues where anthocyanidin-derived $\mathrm{C}_{6}-\mathrm{C}_{3}-\mathrm{C}_{6}$ products are localized. Molecular modelling studies have shown that some flavonoids, including quercetin, can be positioned at the membrane-aqueous interface and contribute to antioxidant defense in the membrane by shuttling protons from the aqueous phase [104,105].

Systemic delivery of anthocyanins and anthocyanidins throughout the body was hypothesized to occur via a 'glucuronide conveyor' [27]. According to the hypothesis, polar glucuronides reach peripheral tissues via systemic circulation. Then glucuronides are deconjugated by peripheral 
glucuronidase activity, releasing anthocyanidins or anthocyanins of reduced polarity which are available for association with the biomatrix and for tissue uptake. Notably, peripheral glucuronidase activity can be affected by stresses such as inflammation [27]. Such a conveyor could provide a means to widely distribute anthocyanin-derived $\mathrm{C}_{6}-\mathrm{C}_{3}-\mathrm{C}_{6}$ products throughout the body.

The possible broad deposition of anthocyanins in body fluids and tissues raises an interesting issue with respect to rodent versus human research models. Whereas lab animals will have had no previous exposure to anthocyanins, humans will have had life-long dietary exposure to them. This factor could affect the capacity to absorb and respond to anthocyanins by rodents in comparison to humans.

\section{Methods to Study Anthocyanin Bioavailability}

The review on anthocyanin deposition in tissues [78] stated that the greatest limitation in comparing research findings was the heterogeneity in the research methodologies, which is indeed valid for all aspects of anthocyanin ADME research. Notably, analytical methods for the ex vivo analysis of anthocyanin in biomatrices continue to improve. LC-MS/MS technologies for sensitive and accurate mass identification have advanced substantially and are well suited for tracking a single drug.

The difficulty with anthocyanin bioavailability research is first, the large number of parent anthocyanins consumed in plant foods, and second the large suite of flavonoid and non-flavonoid products, including glycosidic and non-glycosidic conjugates emanating from each parent anthocyanin over time and sites within the body. Analytical methods must, therefore, focus on tracking the largest number of predicted moieties possible, and then apply data analytics and modelling to build a more inclusive, rather than reductive model to understand the behavior of anthocyanins in vivo and how they support health.

Anthocyanin metabolism in vivo affects molecular size and polarity and, as a result, alters metabolite solubility among biomatrices (Table 1). This aspect probably contributes to inconsistencies among reports, including approaches to sample handling and analysis. Targeted sample clean-up [60,89] and optimized LC-MS conditions in positive ion mode, plus data mining and modeling are key requirements in investigating the complex ADME of anthocyanins. Pure analytical standards are mostly not commercially available for use in the identification of $C_{6}-C_{3}-C_{6}$ based conjugates of anthocyanins and anthocyanidins and therefore, this potentially important group of early anthocyanin metabolites has not been well-studied. Notably, there are no published descriptions of artifacts related to flavonoid conjugate detection using LC-MS/MS.

\section{Conclusions}

Site-specific conditions contribute to a variety of physical and metabolic events that affect the structure and properties of anthocyanins in vivo (Table 1). As a result, the ADME of anthocyanins involves a diverse pool of both $\mathrm{C}_{6}-\mathrm{C}_{3}-\mathrm{C}_{6}$ and $\mathrm{C}_{6}-\mathrm{C}_{\mathrm{n}}$ metabolites which appear to collectively benefit health in a variety of ways. To date, there is no unambiguous evidence pointing to the bioactivity of any specific anthocyanin product(s) in vivo. Indeed, with consideration of the ecological role of anthocyanins as foods, they do not have the potency nor the behavior of drugs. Instead of acting as single agents, with limited in vivo actions, a multitude of products and actions are derived from anthocyanins in vivo. 
Table 1. Sites of occurrence of anthocyanins and their $C_{6}-C_{3}-C_{6}$ products in vivo, and the events and effects associated with them.

\begin{tabular}{|c|c|c|c|}
\hline Site & Event & Effect & Reference \\
\hline Mouth & $\begin{array}{l}\text { Deglycosylation } \\
\text { Association with saliva proteins }\end{array}$ & $\begin{array}{c}\text { Polarity decrease; membrane } \\
\text { solubility increase } \\
\text { Decline in free parent anthocyanin }\end{array}$ & {$[22,47]$} \\
\hline Stomach & $\begin{array}{l}\text { Uptake on bilitranslocase } \\
\text { Stabilization by acidic } \mathrm{pH}\end{array}$ & $\begin{array}{l}\text { Rapid absorption and distribution } \\
\text { of parent anthocyanins }\end{array}$ & {$[44,77]$} \\
\hline Small intestine & $\begin{array}{l}\text { Association with food matrix } \\
\text { Association with intestinal mucin } \\
\text { High concentration in small } \\
\text { intestine } \\
\text { Enteric transport and phase } 2 \\
\text { metabolism }\end{array}$ & $\begin{array}{l}\text { Increased stability } \\
\text { Delayed, impeded absorption } \\
\text { Antioxidant effect in small intestine } \\
\text { Distribution and formation of phase } \\
\quad 2 \text { conjugates }\end{array}$ & {$[22,27,103]$} \\
\hline Liver & Hepatic phase 2 metabolism & Formation of phase 2 conjugates & [106] \\
\hline Large intestine & Survival in colon & $\begin{array}{l}\text { Darkening and purple coloration of } \\
\text { feces (e.g., birds and bears) } \\
\text { Antioxidant protection in colon }\end{array}$ & [103] \\
\hline Bile & $\begin{array}{l}\text { Dissolution of anthocyanins and } \\
\text { their metabolites in amphipathic bile }\end{array}$ & $\begin{array}{c}\text { Capacity for enterohepatic } \\
\text { circulation due to anthocyanin } \\
\text { properties } \\
\text { Complex pool of anthocyanin } \\
\text { isomers }\end{array}$ & [56] \\
\hline Plasma & $\begin{array}{l}\text { Association with serum albumin } \\
\text { Preferred protein association with } \\
\text { anthocyanin glycosides }\end{array}$ & $\begin{array}{l}\text { Increased anthocyanin stability } \\
\text { Depot for protein-associated } \\
\text { anthocyanin }\end{array}$ & [32] \\
\hline Tissues & Association with tissues & $\begin{array}{l}\text { Long-term retention and possible } \\
\text { protection of membranes and other } \\
\text { structures }\end{array}$ & {$[78,104]$} \\
\hline $\begin{array}{l}\text { Liposomes and } \\
\text { micelles }\end{array}$ & Reduced water activity & $\begin{array}{l}\text { Increased anthocyanin stability } \\
\text { Differential distribution and } \\
\text { mobility in membranes }\end{array}$ & {$[25,26]$} \\
\hline
\end{tabular}

Research perspectives should aim to not be reductionist in nature. While anthocyanin bioavailability research has historically been focused on the low MW phenolic catabolites of anthocyanins, the distinct and diverse chemical properties of various $\mathrm{C}_{6}-\mathrm{C}_{3}-\mathrm{C}_{6}$, anthocyanin-derived products warrant more attention. These metabolites possess the distinctive flavonoid structure, which is associated with bioactivity.

Large inter-individual variation is documented in phenotypic factors [36,50] and pharmacokinetics [18] for anthocyanin metabolism in humans. This is mostly due to human, and not microbial metabolism, and is an obstacle in developing generalizable knowledge that can guide future research.

Funding: No external funding was received for the preparation of this review.

Conflicts of Interest: The author declares no conflict of interest.

\section{Abbreviations}

ADME absorption, digestion, metabolism and excretion

C3g cyanidin-3-glucoside

EHC enterohepatic circulation

GIT gastrointestinal tract

Mal3g malvidin-3-glucoside

MEKC micellar electrokinetic capacity

Peo3g peonidin-3-glucoside 


\section{References}

1. Ivey, K.L.; Jensen, M.K.; Hodgson, J.M.; Eliassen, A.H.; Cassidy, A.; Rimm, E.B. Association of flavonoid-rich foods and flavonoids with risk of all-cause mortality. Br. J. Nutr. 2017, 117, 1470-1477. [CrossRef] [PubMed]

2. Middleton, E.; Kandaswami, C. The impact of plant flavonoids on mammalian biology: Implications for immunity, inflammation and cancer. In The Flavonoids Advances in Research; Routledge: London, UK, 1993; pp. 619-652. [CrossRef]

3. Morais, C.A.; de Rosso, V.V.; Estadella, D.; Pisani, L.P. Anthocyanins as inflammatory modulators and the role of the gut microbiota. J. Nutr Biochem. 2016. [CrossRef] [PubMed]

4. Pojer, E.; Mattivi, F.; Johnson, D.; Stockley, C.S. The case for anthocyanin consumption to promote human health: A review. Compr. Rev. Food Sci. Food Saf. 2013, 12, 483-508. [CrossRef]

5. Grosso, G.; Micek, A.; Godos, J.; Pajak, A.; Sciacca, S.; Galvano, F.; Giovanucci, E.L. Dietary flavonoid and lignan intake and mortality in prospective cohort studies: Systematic review and dose-response meta-analysis. Am. J. Epidemiol. 2017, 185, 1304-1316. [CrossRef]

6. Wang, X.; Ouyang, Y.Y.; Liu, J.; Zhao, G. Flavonoid intake and risk of CVD: A systematic review and meta-analysis of prospective cohort studies. Br. J. Nutr. 2014, 1-11. [CrossRef]

7. Goetz, M.E.; Judd, S.E.; Safford, M.M.; Hartman, T.J.; McClellan, W.M.; Vaccarino, V. Dietary flavonoid intake and incident coronary heart disease: The REasons for Geographic and Racial Differences in Stroke (REGARDS) study. Am. J. Clin. Nutr. 2016, 104, 1236-1244. [CrossRef]

8. Cassidy, A.; Bertoia, M.; Chiuve, S.; Flint, A.; Forman, J.; Rimm, E.B. Habitual intake of anthocyanins and flavanones and risk of cardiovascular disease in men. Am. J. Clin. Nutr. 2016, 104, 587-594. [CrossRef]

9. Du, H.; Li, L.; Bennett, D.; Guo, Y.; Key, T.J.; Bian, Z.; Sherliker, P.; Gao, H.; Chen, Y.; Yang, L.; et al. Fresh fruit consumption and major cardiovascular disease in China. J. Med. 2016, 374, 1332-1343. [CrossRef]

10. Yang, L.; Ling, W.; Du, Z.; Chen, Y.; Li, D.; Deng, S.; Liu, Z.; Yang, L. Effects of anthocyanins on cardiometabolic health: A systematic review and meta-analysis of randomized controlled trials. Adv. Nutr. 2017, 8, 684-693. [CrossRef]

11. Cassidy, A.; Mukamal, K.J.; Liu, L.; Franz, M.; Eliassen, A.H.; Rimm, E.B. High anthocyanin intake is associated with a reduced risk of myocardial infarction in young and middle-aged women. Circulation 2013, 127, 188-196. [CrossRef]

12. Jennings, A.; Welch, A.A.; Fairweather-Tait, S.J.; Kay, C.; Minihane, A.-M.; Chowienczyk, P.; Jiang, B.; Cecelja, M.; Spector, T.; MacGregor, A.; et al. Higher anthocyanin intake is associated with lower arterial stiffness and central blood pressure in women. Am. J. Clin. Nutr. 2012, 96, 781-788. [CrossRef]

13. Cassidy, A.; O’Reilly, E.J.; Kay, C.; Sampson, L.; Franz, M.; Forman, J.P.; Curham, G.; Rimm, E.B. Habitual intake of flavonoid subclasses and incident hypertension in adults. Am. J. Clin. Nutr. 2011, 93, 338-347. [CrossRef] [PubMed]

14. Wedick, N.M.; Pan, A.; Cassidy, A.; Rimm, E.B.; Sampson, L.; Rosner, B.; Willett, W.; Hu, F.B.; Sun, Q.; van Dam, R.M. Dietary flavonoid intakes and risk of type 2 diabetes in US men and women. Am. J. Clin. Nutr. 2012, 95, 925-933. [CrossRef] [PubMed]

15. Bertoia, M.L.; Rimm, E.B.; Mukamal, K.J.; Hu, F.B.; Willett, W.C.; Cassidy, A. Dietary flavonoid intake and weight maintenance: Three prospective cohorts of 124,086 US men and women followed for up to 24 years. BMJ 2016, 352, i17. [CrossRef] [PubMed]

16. Devore, E.; Hee, K.J.; Breteler, M.; Grodstein, F. Dietary intakes of berries and flavonoids in relation to cognitive decline. Ann. Neurol. 2012, 72, 135-143. [CrossRef] [PubMed]

17. Manach, C.; Williamson, G.; Morand, C.; Scalbert, A.; Rémésy, C. Bioavailability and bioefficacy of polyphenols in humans. I. Review of 97 bioavailability studies. Am. J. Clin. Nutr. 2005, 81, 230S-242S. [CrossRef]

18. Czank, C.; Cassidy, A.; Zhang, Q.; Morrison, D.J.; Preston, T.; Kroon, P.; Botting, N.; Kay, C.D. Human metabolism and elimination of the anthocyanin, cyanidin-3-glucoside: A 13C-tracer study. Am. J. Clin. Nutr. 2013, 97, 995-1003. [CrossRef]

19. de Ferrars, R.M.; Cassidy, A.; Curtis, P.; Kay, C.D. Phenolic metabolites of anthocyanins following a dietary intervention study in post-menopausal women. Mol. Nutr. Food Res. 2014, 58. [CrossRef]

20. Woodward, G.; Kroon, P.; Cassidy, A.; Kay, C. Anthocyanin stability and recovery: Implications for the analysis of clinical and experimental samples. J. Agric. Food Chem. 2009, 57, 5271-5278. [CrossRef] 
21. Wu, X.; Pittman, H.E.; Prior, R.L. Fate of anthocyanins and antioxidant capacity in contents of the gastrointestinal tract of weanling pigs following black raspberry consumption. J. Agric. Food Chem. 2006, 54, 583-589. [CrossRef]

22. He, J.; Wallace, T.C.; Keatley, K.E.; Failla, M.L.; Giusti, M.M. Stability of black raspberry anthocyanins in the digestive tract lumen and transport efficiency into gastric and small intestinal tissues in the rat. J. Agric. Food Chem. 2009, 57, 3141-3148. [CrossRef] [PubMed]

23. Talavéra, S.; Felgines, C.; Texier, O.; Besson, C.; Manach, C.; Lamaison, J.-L.; Remesey, C. Anthocyanins are efficiently absorbed from the small intestine in rats. J. Nutr. 2004, 134, 2275-2279. [CrossRef] [PubMed]

24. Garzón, G.A.; Wrolstad, R.E. The stability of pelargonidin-based anthocyanins at varying water activity. Food Chem. 2001, 75, 185-196. [CrossRef]

25. Lima, J.C.; Vautier-Giongo, C.; Lopes, A.; Melo, E.; Quina, F.H.; Maçanita, A.L. Color stabilization of anthocyanins: Effect of SDS micelles on the acid-base and hydration kinetics of malvidin 3-glucoside (Oenin). J. Phys. Chem A. 2002, 106, 5851-5859. [CrossRef]

26. Mulinacci, N.; Romani, A.; Pinelli, P.; Gallori, S.; Giaccherini, C.; Vincieri, F.F. Stabilisation of natural anthocyanins by micellar systems. Int J. Pharm. 2001, 216, 23-31. [CrossRef]

27. Gonzales, G.B.; Smagghe, G.; Grootaert, C.; Zotti, M.; Raes, K.; Van Camp, J. Flavonoid interactions during digestion, absorption, distribution and metabolism: A sequential structure-activity/property relationship-based approach in the study of bioavailability and bioactivity. Drug Metab. Rev. 2015, 47, 175-190. [CrossRef]

28. Müller, L.; Bednář, P.; Barták, P.; Lemr, K.; Ševčík, J. Estimation of partition coefficients by MEKC Part 2: Anthocyanins. J. Sep. Sci. 2005, 28, 1285-1290. [CrossRef]

29. Kay, C.D. Aspects of anthocyanin absorption, metabolism and pharmacokinetics in humans. Nutr. Res. Rev. 2006, 19, 137-146. [CrossRef]

30. Le Bourvellec, C.; Renard, C.M.G.C. Interactions between polyphenols and macromolecules: Quantification methods and mechanisms. Crit. Rev. Food Sci. Nutr. 2012, 52, 213-248. [CrossRef]

31. Kaldas, M.I.; Walle, U.K.; van der Woude, H.; McMillan, J.M.; Walle, T. Covalent binding of the flavonoid quercetin to human serum albumin. J. Agric. Food Chem. 2005, 53, 4194-4197. [CrossRef]

32. Cahyana, Y.; Gordon, M.H. Interaction of anthocyanins with human serum albumin: Influence of $\mathrm{pH}$ and chemical structure on binding. Food Chem. 2013, 141, 2278-2285. [CrossRef] [PubMed]

33. Murkovic, M.; Adam, U.; Pfannhauser, W. Analysis of anthocyane glycosides in human serum. Fresenius J. Anal. Chem. 2000, 366, 379-381. [CrossRef] [PubMed]

34. Talavéra, S.; Felgines, C.; Texier, O.; Besson, C.; Lamaison, J.-L.; Rémésy, C. Anthocyanins are efficiently absorbed from the stomach in anesthetized rats. J. Nutr. 2003, 133, 4178-4182. [CrossRef] [PubMed]

35. Kalt, W.; McDonald, J.E.; Vinqvist-Tymchuk, M.R.; Liu, Y.; Fillmore, S.A.E. Human anthocyanin bioavailability: Effect of intake duration and dosing. Food Funct. 2017, 8, 4563-4569. [CrossRef]

36. Kirakosyan, A.; Seymour, E.M.; Wolforth, J.; McNish, R.; Kaufman, P.B.; Bolling, S.F. Tissue bioavailability of anthocyanins from whole tart cherry in healthy rats. Food Chem. 2015, 171, 26-31. [CrossRef]

37. Del Bò, C.; Ciappellano, S.; Klimis-Zacas, D.; Martini, D.; Gardana, C.; Riso, P.; Porrini, M. Anthocyanin absorption, metabolism, and distribution from a wild blueberry-enriched diet (Vaccinium angustifolium) is affected by diet duration in the Sprague-Dawley rat. J. Agric. Food Chem. 2010, 58, 2491-2497. [CrossRef] [PubMed]

38. Macierzanka, A.; Rigby, N.M.; Corfield, A.P.; Wellner, N.; Bottger, F.; Clare Mills, E.N.; Mackie, A.R. Adsorption of bile salts to particles allows penetration of intestinal mucus. Soft Matter 2011, 7, 8077-8084. [CrossRef]

39. Chen, I.-L.; Tsai, Y.-J.; Huang, C.-M.; Tsai, T.-H. Lymphatic absorption of quercetin and rutin in rat and their pharmacokinetics in systemic plasma. J. Agric. Food Chem. 2010, 58, 546-551. [CrossRef]

40. Murota, K.; Terao, J. Quercetin appears in the lymph of unanesthetized rats as its phase II metabolites after administered into the stomach. FEBS Lett. 2005, 579, 5343-5346. [CrossRef]

41. Mullen, W.; Edwards, C.A.; Serafini, M.; Crozier, A. Bioavailability of pelargonidin-3-O-glucoside and its metabolites in humans following the ingestion of strawberries with and without cream. J. Agric. Food Chem. 2008, 56, 713-719. [CrossRef]

42. Lesser, S.; Cermak, R.; Wolffram, S. Bioavailability of quercetin in pigs is influenced by the dietary fat content. J. Nutr. 2004, 134, 1508. [CrossRef] [PubMed] 
43. Passamonti, S.; Vrhovsek, U.; Mattivi, F. The interaction of anthocyanins with bilitranslocase. Biochem Biophys. Res. Commun. 2002, 296, 631-636. [CrossRef]

44. Passamonti, S.; Terdoslavich, M.; Franca, R.; Vanzo, A.; Tramer, F.; Braidor, E.; Petrussa, E.; Vianello, A. Bioavailability of flavonoids: A review of their membrane transport and the function of bilitranslocase in animal and plant organisms. Curr. Drug Metab. 2009, 10, 369-394. [CrossRef] [PubMed]

45. Zhang, L.; Zuo, Z.; Lin, G. Intestinal and hepatic glucuronidation of flavonoids. Mol. Pharm. 2007, 4, 833-845. [CrossRef] [PubMed]

46. Fang, J. Some anthocyanins could be efficiently absorbed across the gastrointestinal mucosa: Extensive presystemic metabolism reduces apparent bioavailability. J. Agric. Food Chem. 2014, 62, 3904-3911. [CrossRef] [PubMed]

47. Kamonpatana, K.; Giusti, M.M.; Chitchumroonchokchai, C.; Moreno-Cruz, M.; Riedl, K.M.; Kumar, P.; Failla, M.L. Susceptibility of anthocyanins to ex vivo degradation in human saliva. Food Chem. 2012, 135, 738-747. [CrossRef]

48. Day, A.J.; DuPonta, M.S.; Ridley, S.; Rhodes, M.; Rhodes, M.J.C.; Morgan, M.R.A.; Williamson, G. Deglycosylation of flavonoid and isoflavonoid glycosides by human small intestine and liver $\beta$-glucosidase activity. FEBS Lett. 1998, 436, 71-75. [CrossRef]

49. Németh, K.; Plumb, G.W.; Berrin, J.G.; Juge, N.; Jacob, R.; Naim, H.Y.; Williamson, G.; Swallow, D.M.; Kroon, P.A. Deglycosylation by small intestinal epithelial cell $\beta$-glucosidases is a critical step in the absorption and metabolism of dietary flavonoid glycosides in humans. Eur. J. Nutr. 2003, 42, 29-42. [CrossRef]

50. Charron, C.S.; Kurilich, A.C.; Clevidence, B.A.; Simon, P.W.; Harrison, D.J.; Britz, S.J.; Baer, D.J.; Novotny, J.A. Bioavailability of anthocyanins from purple carrot juice: Effects of acylation and plant matrix. J. Agric. Food Chem. 2009, 57, 1226-1230. [CrossRef]

51. Kurilich, A.C.; Clevidence, B.A.; Britz, S.J.; Simon, P.W.; Novotny, J.A. Plasma and urine responses are lower for acylated vs. nonacylated anthocyanins from raw and cooked purple carrots. J. Agric. Food Chem. 2005, 53, 6537-6542. [CrossRef]

52. He, J.; Magnuson, B.A.; Lala, G.; Tian, Q.; Schwartz, S.J.; Giusti, M.M. Intact anthocyanins and metabolites in rat urine and plasma after 3 months of anthocyanin supplementation. Nutr. Cancer. 2006, 54, 3-12. [CrossRef] [PubMed]

53. Cooney, J.M.; Jensen, D.J.; McGhie, T.K. LC-MS identification of anthocyanins in boysenberry extract and anthocyanin metabolites in human urine following dosing. J. Sci. Food Agric. 2004, 84, 237-245. [CrossRef]

54. Matuschek, M.C.; Hendriks, W.H.; McGhie, T.K.; Reynolds, G.W. The jejunum is the main site of absorption for anthocyanins in mice. J. Nutr. Biochem. 2006, 17, 31-36. [CrossRef] [PubMed]

55. Marczylo, T.H.; Cooke, D.; Brown, K.; Steward, W.P.; Gescher, A.J. Pharmacokinetics and metabolism of the putative cancer chemopreventive agent cyanidin-3-glucoside in mice. Cancer Chemother Pharmacol. 2009, 64, 1261-1268. [CrossRef] [PubMed]

56. Kalt, W.; McDonald, J.E.; Liu, Y.; Fillmore, S.A.E. Flavonoid metabolites in human urine during blueberry anthocyanin intake. J. Agric. Food Chem. 2017, 65, 1582-1591. [CrossRef]

57. Vanzo, A.; Terdoslavich, M.; Brandoni, A.; Torres, A.M.; Vrhovsek, U.; Passamonti, S. Uptake of grape anthocyanins into the rat kidney and the involvement of bilitranslocase. Mol. Nutr. Food Res. 2008, 52, 1106-1116. [CrossRef]

58. Felgines, C.; Texier, O.; Garcin, P.; Besson, C.; Lamaison, J.L.; Scalbert, A. Tissue distribution of anthocyanins in rats fed a blackberry anthocyanin-enriched diet. Mol. Nutr. Food Res. 2009, 53, 1098-1103. [CrossRef]

59. Ichiyanagi, T.; Shida, Y.; Rahman, M.M.; Hatano, Y.; Konishi, T. Extended glucuronidation is another Major path of cyanidin 3-O- $\beta$-D-glucopyranoside metabolism in rats. J. Agric. Food Chem. 2005, 53, 7312-7319. [CrossRef]

60. Mueller, D.; Jung, K.; Winter, M.; Rogoll, D.; Melcher, R.; Richling, E. Human intervention study to investigate the intestinal accessibility and bioavailability of anthocyanins from bilberries. Food Chem. 2017, 231, 275-286. [CrossRef]

61. Kalt, W.; Liu, Y.; McDonald, J.E.; Vinqvist-Tymchuk, M.R.; Fillmore, S.A.E. Anthocyanin metabolites are abundant and persistent in human urine. J. Agric. Food Chem. 2014, 62, 3926-3934. [CrossRef]

62. Wu, B.; Kulkarni, K.; Basu, S.; Zhang, S.; Hu, M. First-pass metabolism via UDP-glucuronosyltransferase: A barrier to oral bioavailability of phenolics. J. Pharm. Sci. 2011, 100, 3655-3681. [CrossRef] [PubMed] 
63. Liu, Z.; Hu, M. Natural polyphenol disposition via coupled metabolic pathways. Expert Opin Drug Metab. Toxicol. 2007, 3, 389-406. [CrossRef] [PubMed]

64. Roberts, M.; Magnusson, B.; Burczynski, F.; Weiss, M. Enterohepatic circulation. Clin. Pharmacokinet. 2002, 41, 751-790. [CrossRef] [PubMed]

65. Lafay, S.; Morand, C.; Manach, C.; Besson, C.; Scalbert, A. Absorption and metabolism of caffeic acid and chlorogenic acid in the small intestine of rats. Br. J. Nutr. 2006, 96, 39-46. [CrossRef] [PubMed]

66. Crespy, V.; Morand, C.; Besson, C.; Cotelle, N.; Vezin, H.; Demigne, C.; Remesey, C. The splanchnic metabolism of flavonoids highly differed according to the nature of the compound. Am. J. Gastro. Liver Physiol. 2003, 284, G980-G988. [CrossRef] [PubMed]

67. Sfakianos, J.; Coward, L.; Kirk, M.; Barnes, S. Intestinal uptake and biliary excretion of the isoflavone genistein in rats. J. Nutr. 1997, 127, 1260-1268. [CrossRef]

68. Zeng, M.; Sun, R.; Basu, S.; Ma, Y.; Ge, S.; Yin, T.; Gao, S.; Zhang, J.; Hu, M. Disposition of flavonoids via recycling: Direct biliary excretion of enterically or extrahepatically derived flavonoid glucuronides. Mol. Nutr. Food Res. 2016, 60, 1006-1019. [CrossRef]

69. Chen, Z.; Zheng, S.; Li, L.; Jiang, H. Metabolism of flavonoids in humans: A comprehensive review. Curr. Drug Metab. 2014, 15, 48-61. [CrossRef]

70. Stalmach, A.; Edwards, C.A.; Wightman, J.D.; Crozier, A. Gastrointestinal stability and bioavailability of (poly)phenolic compounds following ingestion of Concord grape juice by humans. Mol. Nutr. Food Res. 2012, 56, 497-509. [CrossRef]

71. Matsumoto, H.; Ichiyanagi, T.; Iida, H.; Ito, K.; Tsuda, T.; Hirayama, M.; Konishi, T. Ingested delphinidin-3-rutinoside is primarily excreted to urine as the intact form and to bile as the methylated forms in rats. J. Agric. Food Chem. 2006, 54, 578-582. [CrossRef]

72. Passamonti, S.; Vrhovsek, U.; Vanzo, A.; Fulvio, M. The stomach as a site for anthocyanins absorption from food. FEBS Lett. 2003, 544, 210-213. [CrossRef]

73. Ichiyanagi, T.; Shida, Y.; Rahman, M.M.; Hatano, Y.; Matsumoto, H.; Hirayama, M.; Konishi, T. Metabolic pathway of cyanidin 3-O- $\beta$-d-glucopyranoside in rats. J. Agric. Food Chem. 2005, 53, 145-150. [CrossRef] [PubMed]

74. Felgines, C.; Krisa, S.; Mauray, A.; Besson, C.; Lamaison, J.-L.; Scalbert, A.; Merillon, J.-M.; Texier, O. Radiolabelled cyanidin 3-O-glucoside is poorly absorbed in the mouse. Br. J. Nutr. 2010, 103, 1738-1745. [CrossRef] [PubMed]

75. Felgines, C.; Talavera, S.; Texier, O.; Gil-Izquierdo, A.; Lamaison, J.L.; Remesy, C. Blackberry anthocyanins are mainly recovered from urine as methylated and glucuronidated conjugates in humans. J. Agric. Food Chem. 2005, 53, 7721-7727. [CrossRef] [PubMed]

76. Fornasaro, S.; Ziberna, L.; Gasperotti, M.; Tramer, F.; Vrhovsek; Mattivi, F.; Passamonti, S. Determination of cyanidin 3-glucoside in rat brain, liver and kidneys by UPLC/MS-MS and its application to a short-term pharmacokinetic study. Sci. Rep. 2016, 6, 1-11. [CrossRef] [PubMed]

77. Vanzo, A.; Vrhovsek, U.; Tramer, F.; Mattivi, F.; Passamonti, S. Exceptionally fast uptake and metabolism of cyanidin 3-glucoside by rat kidneys and liver. J. Nat. Prod. 2011, 74, 1049-1054. [CrossRef] [PubMed]

78. Sandoval-Ramírez, B.A.; Catalán, Ú.; Fernández-Castillejo, S.; Rubió, L.; Macià, A.; Solà, R. Anthocyanin tissue bioavailability in animals: Possible implications for human health. A systematic review. J. Agric. Food Chem. 2018, 66, 11531-11543. [CrossRef]

79. Chen, T.Y.; Kritchevsky, J.; Hargett, K.; Feller, K.; Klobusnik, R.; Song, B.J.; Cooper, B.; Jouni, Z.; Ferruzzi, M.G.; Janle, E.M. Plasma bioavailability and regional brain distribution of polyphenols from apple/grape seed and bilberry extracts in a young swine model. Mol. Nutr Food Res. 2015, 59, 2432-2447. [CrossRef]

80. Kalt, W.; Blumberg, J.B.; McDonald, J.E.; Vinqvist-Tymchuk, M.R.; Fillmore, S.A.E.; Graf, B.A.; O'Leary, J.M.; Milbury, P.E. Identification of anthocyanins in the liver, eye, and brain of blueberry-fed pigs. J. Agric. Food Chem. 2008, 705-712. [CrossRef]

81. Milbury, P.E.; Kalt, W. Xenobiotic metabolism and berry flavonoid transport across the blood brain barrier. J. Agric. Food Chem. 2010, 58, 3950-3956. [CrossRef]

82. Sakakibara, H.; Ogawa, T.; Koyanagi, A.; Kobayasho, S.; Goda, T.; Kumazawa, S.; Kobayashi, H.; Shimoi, K. Distribution and excretion of bilberry anthocyanins in mice. J. Agric. Food Chem. 2009, 57, 7681-7686. [CrossRef] [PubMed] 
83. Wen, X.; Walle, T. Methylated flavonoids have greatly improved intestinal absorption and metabolic stability. Drug Metab. Dispos. 2006, 34, 1786-1792. [CrossRef] [PubMed]

84. Zimman, A.; Waterhouse, A.L. Enzymatic synthesis of [3'-O-methyl- $\left.{ }^{3} \mathrm{H}\right]$ malvidin-3-glucoside from petunidin-3-glucoside. J. Agric. Food Chem. 2002, 50, 2429-2431. [CrossRef] [PubMed]

85. Carkeet, C.; Clevidence, B.A.; Novotny, J.A. Anthocyanin excretion by humans increases linearly with increasing strawberry dose. J. Nutr. 2008, 138, 897-902. [CrossRef]

86. El Mohsen, M.A.; Marks, J.; Kuhnle, G.; Moore, K.; Debnam, E.; Srai, S.K.; Rice-Evans, C.; Spencer, J.P.E. Absorption, tissue distribution and excretion of pelargonidin and its metabolites following oral administration to rats. Br. J. Nutr. 2006, 95, 51. [CrossRef]

87. Prior, R.L. Anthocyanins: Understanidng their absorption and metabolism. In Flavonoids and Related Compounds: Bioavailability and Function; Spencer, J.P., Crozier, A., Eds.; CRC Press: Boca Raton, FL, USA, 2007; pp. 79-92.

88. Kalt, W.; McDonald, J.E.; Ricker, R.D.; Lu, X. Anthocyanin content and profile within and among blueberry species. Can. J. Plant. Sci. 1999, 79, 617-623. [CrossRef]

89. Aqil, F.; Vadhanam, M.V.; Jeyabalan, J.; Cai, J.; Singh, I.P.; Gupta, R.C. Detection of anthocyanins/ anthocyanidins in animal tissues. J. Agric. Food Chem. 2014, 62, 3912-3918. [CrossRef] [PubMed]

90. Ichiyanagi, T.; Shida, Y.; Rahman, M.M.; Hatano, Y.; Konishi, T. Bioavailability and tissue distribution of anthocyanins in bilberry (Vaccinium myrtillus L.) extract in rats. J. Agric. Food Chem. 2006, 54, 6578-6587. [CrossRef]

91. Borges, G.; Roowi, S.; Rouanet, J.-M.; Duthie, G.G.; Lean, M.E.J.; Crozier, A. The bioavailability of raspberry anthocyanins and ellagitannins in rats. Mol. Nutr. Food Res. 2007, 51, 714-725. [CrossRef]

92. Del Bo', C.; Roursgaard, M.; Porrini, M.; Loft, S.; Møller, P.; Riso, P. Different effects of anthocyanins and phenolic acids from wild blueberry (Vaccinium angustifolium) on monocytes adhesion to endothelial cells in a TNF- $\alpha$ stimulated proinflammatory environment. Mol. Nutr. Food Res. 2016, 60. [CrossRef]

93. Talavéra, S.; Felgines, C.; Texier, O.; Besson, C.; Gil-Izquierdo, A.; Lamaison, J.-L.; Remesey, C. Anthocyanin metabolism in rats and their distribution to digestive area, kidney, and brain. J. Agric. Food Chem. 2005, 53, 3902-3908. [CrossRef] [PubMed]

94. Passamonti, S.; Vrhovsek, U.; Vanzo, A.; Mattivi, F. Fast access of some grape pigments to the brain. J. Agric. Food Chem. 2005, 53, 7029-7034. [CrossRef] [PubMed]

95. Chen, T.-Y.; Ferruzzi, M.G.; Wu, Q.-L.; Simon, J.E.; Talcott, S.T.; Wang, J.; Ho, L.; Todd, G.; Cooper, B.; Pasinetti, G.M.; et al. Influence of diabetes on plasma pharmacokinetics and brain bioavailability of grape polyphenols and their phase II metabolites in the Zucker diabetic fatty rat. Mol. Nutr. Food Res. 2017, 61, 1700111. [CrossRef] [PubMed]

96. Kalt, W.; Hanneken, A.; Milbury, P.; Tremblay, F. Recent research on polyphenolics in vision and eye health. J. Agric. Food Chem. 2010, 58, 4001-4007. [CrossRef] [PubMed]

97. Matsumoto, H.; Nakamura, Y.; Iida, H.; Ito, K.; Ohguro, H. Comparative assessment of distribution of blackcurrant anthocyanins in rabbit and rat ocular tissues. Exp. Eye Res. 2006, 83, 348-356. [CrossRef] [PubMed]

98. Kay, C.D.; Kroon, P.A.; Cassidy, A. The bioactivity of dietary anthocyanins is likely to be mediated by their degradation products. Mol. Nutr. Food Res. 2009, 53, S92-S101. [CrossRef] [PubMed]

99. Kay, C.D.; Pereira-Caro, G.; Ludwig, I.A.; Clifford, M.N.; Crozier, A. Anthocyanins and flavanones are more bioavailable than previously perceived: A review of recent evidence. Annu. Rev. Food Sci. Technol. 2017, 8, 155-180. [CrossRef]

100. Williamson, G.; Clifford, M.N. Colonic metabolites of berry polyphenols: The missing link to biological activity? Br. J. Nutr. 2010, 104, S48-S66. [CrossRef]

101. Forester, S.C.; Waterhouse, A.L. Metabolites are key to understanding health effects of wine polyphenolics. J. Nutr. 2009, 138, 1824S-1831S. [CrossRef]

102. Forester, S.C.; Waterhouse, A.L. Identification of cabernet sauvignon anthocyanin gut microflora metabolites. J. Agric. Food Chem. 2008, 56, 9299-9304. [CrossRef]

103. Halliwell, B. Dietary polyphenols: Good, bad, or indifferent for your health? Cardiovasc Res. 2007, 73, 341-347. [CrossRef] [PubMed] 
104. Košinová, P.; Berka, K.; Wykes, M.; Otyepka, M.; Trouillas, P. Positioning of antioxidant quercetin and its metabolites in lipid bilayer membranes: Implication for their lipid-peroxidation inhibition. J. Phys. Chem. B. 2012, 116, 1309-1318. [CrossRef] [PubMed]

105. Fabre, G.; Bayach, I.; Berka, K.; Paloncyova, M.; Starok, M.; Rossi, C.; Duroux, J.-L.; Otyepka, M.; Trouillas, P. Synergism of antioxidant action of vitamins $\mathrm{E}, \mathrm{C}$ and quercetin is related to formation of molecular associations in biomembranes. Chem. Comm. 2015, 51, 7713-7716. [CrossRef] [PubMed]

106. Williamson, G.; Kay, C.D.; Crozier, A. The bioavailability, transport, and bioactivity of dietary flavonoids: A review from a historical perspective. Compr Rev. Food Sci. Food Saf. 2018, 17, 1054-1112. [CrossRef]

(C) 2019 by the author. Licensee MDPI, Basel, Switzerland. This article is an open access article distributed under the terms and conditions of the Creative Commons Attribution (CC BY) license (http://creativecommons.org/licenses/by/4.0/). 